\title{
Pléh Csaba
}

Central European University, Budapest, MTA Közoktatási Elnöki Bizottság

\section{Az ezredforduló pszichológiája II $^{1}$}

\section{Az evo-devo: az evolúció és az egyedfejlődés összekapcsolása}

$\Lambda$ z utóbbi évtizedek nagy újdonsága az idegtudományi modellálás, a gyermeki fejlődés és az evolúciós örökség összekapcsolása. Ahogy Robert (2008) fogalmazott, az evolúciós gondolkodás pszichológiai bevezetésének nem a felnőttekkel kapcsolatos, mára már hagyományos evolúciós pszichológia a helyes útja, hanem a fejlődésbiológia leckéinek újragondolása. A pszichológia, akárcsak a biológia, hamar észrevette, hogy az evo-devo gondolkodásnak kulcsszerepe kell legyen. Az evolúciós elkötelezettségeket összekapcsolták a fejlődési mechanizmus gondolatmenetével. Ennek első próbálkozásai a brit fejlődéspszichológus, Annette Karmiloff-Smith (1938-2016) munkájához kapcsolódnak. Karmiloff-Smith magát az emberi gondolkodás moduláris szerveződését is a veleszületett preferenciákon alapuló fejlődési eredményként értelmezte. Az emberi fejlődés nem előhuzalozott modulok kibontakozása lenne, hanem modularizáció, fokozatos specializálódás (Karmiloff-Smith, 1996). Hasonlóan fejtette ezt ki a gyermek fejlődési zavaraira nézve is. A genetikailag is meghatározott fejlődési zavarok nem egyszerüen sajátos képességek elmaradásai lennének. Például az autizmus, ahol a tudatértelmezés hiányát találjuk, a világgal interakcióban lévő gyerek egész fejlődésének dinamikáját befolyásolja, ahol a csecsemőkori viszonylag kicsi különbségek óriási hatással lehetnek a későbbi fejlödésre.

„Az evolúciós biológiában nemcsak a próba-szerencse tanulás analógiája van meg, hanem a fejlődési korlátok fogalmával a kognitív pszichológia analógiája is. A kognitivisták azt hangsúlyozták, hogy a próba-szerencsét olyan komplex belső állapotok közvetíthetik, amelyek a környezeti közvetítettségü tanulás hatását felgyorsítják, lelassítják, vagy kanalizálják. A fejlődési korlátokkal foglalkozó biológusok ugyanezt mondják a természetes kiválasztódás mechanizmusairól. Az embriológiai fejlödés befolyásolja, hogy milyen esélyei vannak a szelekciónak, mit lehet szelektálni. Nem teljes természetesen az analógia, hiszen a fejlődési korlátok nem szándékosak és nem reprezentációs, nem gondolati természetüek. Ugyanakkor saját belső kritikájuk nagyon hasonló volt, ami a kognitivistákat és a korlátokkal érvelöket illeti. A behavioristák a kognitív állapotokat túl mentalisztikusnak címkézték, míg a neodarwinisták a tervrajzokat idealistáknak.” (Amundson, 2006. 10.) Az új törekvések célja, mint arra Garry Marcus (2006) rámutat, hogy a fejlődés proximális mechanizmusait az evolúció disztális mechanizmusaival kapcsolják össze. Ennek során nem pusztán analógiákat keresnek, hanem a két változás-sor közti oksági kapcsolatot, és világos genetikai megfontolásokra alapoznak. Marcus szerint a nativizmus összeilleszthető a tapasztalati hatásokkal. Feltételezhetjük, hogy az agynak van egy kiinduló állapota, ugyanakkor a fejlődés során vannak olyan tényezők, mint például a gén-expresszió, a sejtszerkezetek közti interakció, a chemo-affinitás és a lépcsőzetes differenciáció, amelyek mind szerepet játszanak a genetikailag meghatározott rendszer kialakulásában. Az utóbbi 10-15 évben a veleszületett mechanizmusok, a tanulás, a percepció, valamint a szociális

1 A tanulmány az Akadémiai Kiadó előkészületben lévő Pszichológiai Kézikönyve bevezető fejezetének készül, előző része az Iskolakultúra 2019/9. számában jelent meg. Köszönöm Forgács Bálint (ELTE) kommentárjait, valamit Géczi János főszerkesztő biztatását a megjelentetésre cikk formában. 
tényezők együtt mérlegelődnek, mint amik az ember gondolkodásának és kulturális teljesítményének fejlődését irányítják. Ebben a helyzetben a puszta természet versus nevelés gondolatmenetet felváltja az, hogy milyen mechanizmusok felelösek a kognitív fejlödésért és milyen kölcsönhatás van e mechanizmusok között. Ennek során a viselkedésgenetika relevanciája új módon jelenik meg a mai pszichológiában.

\section{A genetikai gondolkodás és érvelés két fajtája a pszichológiában}

A genetikával kapcsolatos gondolkodásmód szerepe gyökeresen megnőtt az utóbbi fél évszázadban. A 4. ábra mutatja ebben a periódusban a két kulcsfogalom alakulását.

Az 1990-es évektől jól láthatóan igencsak népszerüvé válik a genetikai megfontolások használata a pszichológiában. Ez azért érdekes, mert a genetikai mozzanat, mely eredetileg nagy viták tárgya volt az 1920-30-as években az intelligencia öröklődésével kapcsolatban, az 1960-as években jelenik meg újra, most azonban már két formában, mint a 4. táblázat jellemzi. Két különböző fejlődési modell alakul ki. Az egyik a Chomsky hirdette innátista gondolatmenet, mely az etológiával és más európai ihletésekkel analógiában azt vetette fel, hogy a bonyolult emberi viselkedések genetikai ellenőrzések alatt lehetnek. A másik viszont az egyéni különbségek genetikai értelmezése.
Az új törekvések célja, mint arra Garry Marcus (2006) rámutat, hogy a fejlódés proximális mechanizmusait az evolúció disztális mechanizmusaival kapcsolják össze. Ennek során nem pusztán analógiákat keresnek, hanem a két változás-sor közti oksági kapcsolatot, és világos genetikai megfontolásokra alapoznak. Marcus szerint a nativizmus összeilleszthetó a tapasztalati hatásokkal. Feltételezhetjük, hogy az agynak van egy kiinduló állapota, ugyanakkor a fejlódés során vannak olyan tényezók, mint például a gén-expresszió, a sejtszerkezetek közti interakció, a chemo-affinitás és a lépcsózetes differenciáció, amelyek mind szerepet játszanak a genetikailag meghatározott rendszer kialakulásában.

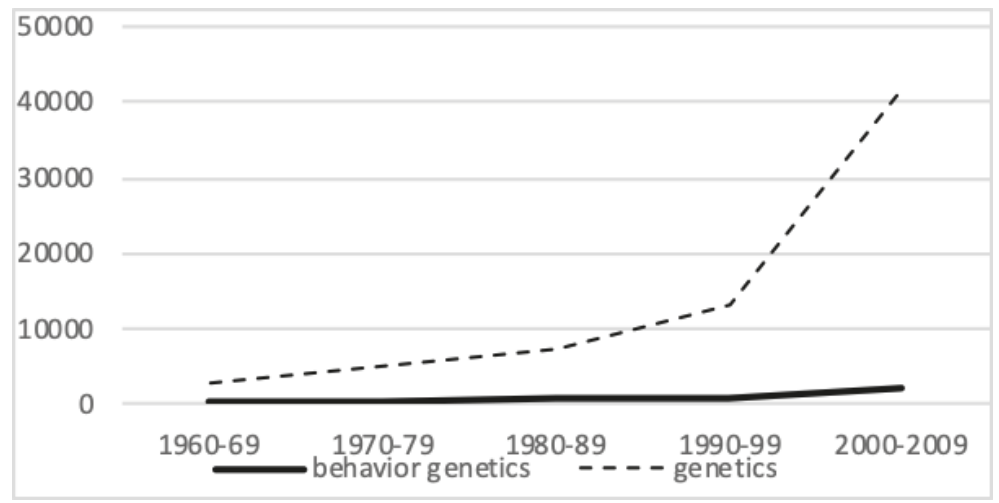

4. ábra A genetika (genetics) és a viselkedés-genetika (behavior genetics) fogalmak népszerüsége a pszichológiai irodalomban 
Pléh Csaba: Az ezredforduló pszichológiája II

4. táblázat. Két felfogás a fejlödés genetikai meghatározottságáról az 1960-as évektöl (Pléh, 2002)

\begin{tabular}{|l|l|l|l|}
\hline \multicolumn{1}{|c|}{ Újítás jellege } & \multicolumn{1}{|c|}{ Fő újdonság } & \multicolumn{1}{c|}{ Ellenfelek } & \multicolumn{1}{c|}{ Vezető képviselök } \\
\hline $\begin{array}{l}\text { Egyetemes } \\
\text { nativizmus }\end{array}$ & $\begin{array}{l}\text { A mentális struktúrák } \\
\text { apriori jellegüek }\end{array}$ & Tanuláselmélet & Chomsky, Fodor \\
\hline $\begin{array}{l}\text { Különbségek } \\
\text { öröklése }\end{array}$ & $\begin{array}{l}\text { Az egyedi különbségek } \\
\text { heritábilisak }\end{array}$ & $\begin{array}{l}\text { Az eltérések } \\
\text { környezeti alapúak }\end{array}$ & $\begin{array}{l}\text { Eysenck, } \\
\text { Arthur Jensen }\end{array}$ \\
\hline $\begin{array}{l}\text { Kritikus } \\
\text { periódusok }\end{array}$ & $\begin{array}{l}\text { A tapasztalat csak } \\
\text { bizonyos időben hatásos }\end{array}$ & $\begin{array}{l}\text { A tapasztalat } \\
\text { kumulatív }\end{array}$ & $\begin{array}{l}\text { Konrad Lorenz, } \\
\text { Erik Lenneberg }\end{array}$ \\
\hline
\end{tabular}

A táblázat első és második sorában látható pszichológiai változatok sokáig külön fejlődtek. Voltak, akiket főleg az érdekelt, és máig az érdekel, hogy bizonyos müködéseknek melyek az általános, a fajra jellemző, feltehetően veleszületett meghatározói, mások viszont az egyéni különbségek genetikai összetevői iránt érdeklődtek. Egy átfogó biológiai elméletben a két kérdés természetesen nem választható külön. A darwini gondolatmenetben a változatok mindenütt jelen vannak és a szelekció a változatokon érvényesül. Az 1930-as évektöl Sir Ronald Fisher munkáiban a genetikai és a darwini érvelést egy tiszta populációs statisztikai módon összekapcsolták. A pszichológiában azonban, egészen máig, ezek javarészt két külön beszédmódként és gondolkodásmódként fejlödtek. Ezt az 1960-as évektől elsők között először Hans Eysenck (1997) emelte ki a pszichológiában is.

\section{A generikus örökség elve}

A generikus innátista csoport Chomsky liberális univerzalista gondolatmenetéből indult ki és egyetemes módon alkalmazta a pszichológiára. Bizonyos képességek, ezeket később területeknek nevezik, mint a nyelv, a számok, az arcfelismerés és hasonlók fejlődése érdekelte, a fajok közti összehasonlítás, a korai kibontakozás, az adott gondolati tartalommal kapcsolatos fejlödési zavarok álltak az érvelésük mögött.

Az innátizmus egyik értelme a behavioristák „üres szervezet” és „fekete doboz” metaforáinak meghaladása volt. A nyelv és más összetett emberi teljesítmények veleszületett szervezödése a biológiában a fajspecifikus viselkedésekhez hasonlít. Chomsky és követői számára ez a típusú meghatározottság nem olyan, mint a klasszikus mechanikus oksági modell. A nyelv, miközben genetikai alapjai vannak, korántsem valamiféle korlátja a gondolkodásnak. Épp ellenkezőleg. Szerkezete révén korlátlan és kerettelen, s így az emberiség korlátlan fejlődésének biztosítéka (Chomsky, 2018). Chomsky szerint a nyelvi kreativitás, mégpedig a mondattani formaalkotás révén adott kreativitás az emberi nyelv legfontosabb jellemzője. Ennek technikai megvalósulása a rekurzivitás, a nyelvi rendszer beépített lehetösége szerkezeteken alapuló egymásba épített szerkezetek (pl. többszörösen összetett mondatok) alkotására. Ugyanakkor ez a formai nyitottság egyben a szabadság kulcsa is. Az emberi nyelv egyetemes vonásai úgy értelmezendők, hogy az egyetemes nyelvtan mintegy választási palettát ad a nyelvet kibontakoztató gyermek számára, 'beállítandó kapcsolók' rendszerét. Van olyan nyelv, amelyben a ragok a fontosak, mint például a magyarban, de van olyan nyelv, amelyben a szórend a fontos, ami a nyelvtani viszonyokat illeti. Chomsky felfogásában az emberi gondolkodásnak bonyolult szerkezetei vannak, melyek nem pusztán mellérendelö asszociatív jellegüek, a gondolkodásnak ugyanúgy, mint a nyelvnek, van grammatikája, sajátos szervezőelvei. Ezek a szervezőelvek alkotják az 'emberi természetet'. Ha gondolkodásunk teljességgel a környezet terméke lenne, akkor éppenséggel ki lennénk szolgáltatva a környezet esetlegességeinek, 
nem lennénk szabadok. A szabadság kulcsa éppen az, hogy gondolatvilágunknak vannak tapasztalatfüggetlen elemei is. Ezek nem sztereotip viselkedéseket határoznak meg, mert a biológiai rendszerként felfogott nyelv legfontosabb vonása az, hogy nyitott rendszer. A nyelv a gondolatalkotási értelemben nem a kifejezés akadálya és korlátja, hanem éppen az ember korlátlan szabad fejlődésének legfőbb biztosítéka. Chomskynak ezt a szabadság és a kreativitás empirista hagyományát nativista módon értelmező felfogása az európai empirista és racionalista filozófiai hagyomány különleges szintézisévé teszi elméletét. Ugyanakkor ezek a szervező elvek a tudatos élmény számára közvetlenül nem hozzáférhetőek. (A nyelvészeti innátista érvelés bemutatására pszichológiai következményeivel együtt ld. Pléh, 2014b.)

A kritikus periódus elméletek az innátista elméletek egy változatát eredményezték. A mai genetikus fejlődéselméletek megjelenése előtt megengedték, hogy az egyéni tapasztalati élmények kiegészítsék a veleszületett mechanizmusokat. Többnyire faj-specifikus és stabil környezeti tényezőkről beszélve, abban az értelemben, ahogyan ezt Donald Hebb bevezette 1949-ben. Hebb (1975) a fejlődés meghatározói közt beszél genetikai tényezőkről, faj-specifikus elvárt környezeti tényezőkröl (pl. hogy egy gyerekhez beszél a környezete) és egyedi környezeti tényezőkröl (pl. hogy keveset beszél hozzá a környezete).

A modern genetika nem ad könnyen módot arra, hogy mereven szembeállítsuk a generikus és a specifikus meghatározottság problémáját. Ezt a Chomskyval mindenben szembenálló Skinner (1963) már a korban észrevette. Kiemelte, hogy Chomsky korai innátista felfogása jellegzetes radikális baloldali társadalomfelfogással kapcsolódik össze. Ez az összekapcsolódás pedig, Skinner koncepciójában, ellentmondásokat rejt magában. Az innátista koncepció el fog vezetni egy különbségalapú genetikai értelmezéshez, ekkor pedig az univerzalista innátista tábornak szembe kell néznie a Jensen (1969) és mások elindította viharral, a társadalmilag megfigyelhető nagyhatású egyéni különbségek genetikai meghatározottságára nézve, vagyis a különbségek genetikájával. Fodor (1998. 207-208.) később ennek a másik oldalát fogalmazza meg: „A kulturális relativizmust széles körben tartják
Chomsky szerint a nyelvi kreativitás, mégpedig a mondattani formaalkotás révén adott kreativitás az emberi nyelv legfontosabb jellemzóje. Ennek techni-

kai megvalósulása a rekurzivitás, a nyelvi rendszer beépitett lehetôsége szerkezeteken alapuló egymásba épitett szerkezetek (pl. többszörösen összetett mondatok) alkotására. Ugyanakkor ez a formai nyitottság egyben a szabadság kulcsa is. Az emberi nyelv egyetemes vonásai úgy értelmezendók, hogy az egyetemes nyelvtan mintegy választási palettát ad a nyelvet kibontakoztató gyermek számára, 'beállitandó kapcso-

lók' rendszerét. Van olyan nyelv, amelyben a ragok a fontosak, mint például a magyarban, de van olyan nyelv, amelyben a szórend a fontos, ami a nyelvtani viszonyokat illeti. Chomsky felfogásában az emberi gondolkodásnak bonyolult szerkezetei vannak, melyek nem pusztán mellérendeló asszociativ jellegúek, a gondolkodásnak ugyanúgy, mint a nyelvnek, van grammatikája, sajátos szervezóelvei. 
politikailag helyesnek. Ha ez így van, a politikai korrektség és a[z univerzalisztikus] kognitív tudomány elöbb vagy utóbb összeütközésbe fognak kerülni."

Chomsky s nyomában Pinker is hitt abban, hogy ez a dilemma feloldható. Pinker a generikus innátista tábor nevében hangsúlyozta, hogy nagyon nehéz egyszerre hinni az egyenlőségben, és elfogadni a különbségeket. Az emberek közötti egyenlőséget ez a generikus tábor erkölcsi alapra helyezi. Pinker hangsúlyozza, hogy hétköznapi gondolkodásunkban nagyon ritkán hiszünk az optimista társadalomfilozófusok ,üres palatábla” hasonlatában. „Szerintem kevés ember hisz komolyan abban, hogy a fiúk és lányok felcserélhetőek lennének; hogy minden intelligencia-különbség a környezetböl fakad; hogy a gyerekek személyiségét a szülők mikro-menedzsmenttel alakíthatják; hogy az embereknek nincsenek önző vonásaik és, hogy a vonzó történetek, dallamok, arcok pusztán társas konstrukciók." (Pinker, 2002. 422.)

A fiatal Chomsky nem rettegett attól, hogy szembenézzen ezekkel a kérdésekkel. Két módon próbálta kezelni a kétféle öröklés előtérbe helyezését. Egyrészt kiemelte, hogy eszmetörténeti szempontból az ember, ha úgy tetszik, nembeliségéhez kapcsolt innátizmus igenis lehet szövetségese a társadalmi progressziónak. Az a hagyományos kettéosztás, mely a racionalizmust (ennek felel meg az innátizmus) inkább a konzervatív, s az empirizmust inkább a progresszív eszmerendszerrel kapcsolja össze, Chomsky szerint a modern időkben megtörik. Ha minden lényeges emberi vonásunk a tapasztalat és a tanulás függvénye lenne, ahogy azt a hagyományos társadalomtudomány hangsúlyozza, akkor nincs kiút a háttérbe szorított vagy elnyomott rétegek számára, a tanulási mechanizmusok révén hátrányuk állandóan öröklődni fog. A velünk született determináció Chomsky felfogásában azonban nem az emberek közötti különbségek kulcsa, hanem az emberi faj azonosságáé. Ha gondolkodásunk teljességgel a környezet terméke lenne, akkor éppenséggel ki lennénk szolgáltatva a környezet esetlegességeinek, nem lennénk szabadok. A szabadság kulcsa éppen az, hogy vannak gondolatvilágunknak tapasztalatfüggetlen elemei is. Ezek azonban nem szetereotip viselkedéseket határoznak meg, mert a biológiai rendszerként felfogott nyelv legfontosabb vonása az, hogy nyitott rendszer. Egy a priori módon meghatározott nyelvtan születik velünk, de ennek tartalma éppen a korlátlanság, az, hogy végtelen számú gondolatot tud kifejezni, mondatot képes létrehozni. A nyelv nem a kifejezés akadálya és korlátja, hanem éppen az ember korlátlan szabad fejlödésének legföbb biztosítéka.

\section{Az innátizmus és az okos csecsemők}

A generikus innátizmus értelmezésében nagy szerepe volt a csecsemőkutatásnak. Azt is lehet mondani, hogy mára újra létrejött egy olyan átfogó fejlődéskutatás, amely a biológiai, pszichológiai és pedagógiai mozzanatokat együtt kezeli. Kiinduló gondolatuk a „kompetens csecsemő”. Az utóbbi évtizedekben ennek kutatását kifinomultabb csecsemővizsgálati technikák teszik lehetővé. A tekintet vizsgálata (a baba arra néz, ami érdekli, vagy arra, amit ismer), a furcsa ingerre fellépő meglepetésnél a hirtelen megváltozó viselkedés és az idegrendszeri eljárások elemzése arra vezetett, hogy ezek a kutatók elkezdték szó szerint értelmezni az innátizmust. A gyermekeket nem pusztán mint megismerö, hanem mint kis tudós lényeket kezdték látni. Olyan lényekként, akik a társas és fizikai környezetükröl elméleteket bontakoztatnak ki, s ezeket az elméleteket próbálják aktív megfigyeléssel vagy kísérletezéssel ellenőrizni. Gopnik és mások egyenesen arról beszélnek, hogy „,bölcsek vannak a bölcsőben”. Az az innátizmus, amelyet Chomsky 40 évvel ezelőtt elindított, mára egy általános kognitív innátizmussá vált. Az elméletalkotó csecsemők teóriájának egyik vezető kutatója Susan Spelke a Harvard Egyetemen. E felfogás szerint van néhány alapvető kognitív rendszer, melyek mintegy tartalomspecifikusak. 
„Az emberek bizonyos dolgokat könnyen, másokat nehezebben tanulnak meg. Ugyanakkor az emberi elme nem masszívan moduláris, ahol speciális kognitív eszközök százai vagy ezrei működnének, hanem csak néhány magrendszer köré épül." (Spelke és Kinzler, 2007. 91-92.) Az egyik alapvető rendszer a tárgyak reprezentációja, ahol a gyerekek nagyon korán koherens, folytonos és megragadható tárgyakat képzelnek el, a másik az ágencia. Olyan társas lények feltételezése, akik célokra irányulnak, és hatékony módszereket használnak e célok elérésére. Kiegészíti ezt a számok és a geometria, valamint a társas reprezentáció rendszere.

\section{Öröklés és egyéni különbségek}

Az egyéni különbségekre nézve két mozzanatot mutatok be: az egyik az intelligencia fejlődése, a másik a különböző betegségekkel való érvelés.

\section{Az intelligencia öröklése}

Az egyéni különbségek öröklésének elve az utóbbi fél évszázadban ugyancsak a behaviorizmus kritikája keretében került újra elötérbe. Az új pszichogenetikusok tagadták, hogy az egyéni különbségek magyarázhatóak lennének az empiristák puszta élettörténeti meséivel. Galtont újítják fel, aki az intelligencia öröklését először hangsúlyozta a 19. század végén, és egyben egy másik mozzanatot is megfogalmazott, miszerint az emberi kiválóságnak egyetlen központi formája van, ezt fejezi ki az intelligencia. Arthur Jensen (1923-2012), a Berkeley Egyetemen tanító neveléspszichológus publikált egy sokat hivatkozott cikket az afroamerikaiak vélt alacsonyabb intelligenciájáról (1969). A provokatív átfogó cikk akkor jelent meg, amikor Amerika tele volt az új társadalom kompenzációs nevelési erőfeszítéseivel Kennedy és Johnson elnökök ideje alatt, hogy valahogyan kiegyenlítsék a társadalmi hátrányokat. A szegénység és a szülök iskolázatlansága lett volna eszerint az iskolai elmaradás fö oka. Jensen ennek az optimista beavatkozási programnak az ellenkezőjét hirdette. A beavatkozások nem vezetnek sikerre, egyszerüen azért, mert a szegények, s különösképpen az
A generikus innátizmus értelmezésében nagy szerepe volt a csecsemókutatásnak. Azt is lehet mondani, hogy mára újra létrejött egy olyan átfogó fejlódéskutatás, amely a biológiai, pszichológiai és pedagógiai mozzanatokat együtt kezeli. Kiinduló gondolatuk a „kompetens csecsemó". Az utóbbi évtizedekben ennek kutatását kifinomultabb csecsemóvizsgálati technikák teszik lehetôvé. A tekintet vizsgálata (a baba arra néz, ami érdekli, vagy arra, amit ismer), a furcsa ingerre fellépó meglepetésnél a hirtelen megváltozó viselkedés és az idegrendszeri eljárások elemzése arra vezetett, hogy ezek a kutatók elkezdték szó szerint értelmezni az innátizmust. A gyermekeket nem pusztán mint megismeró, hanem mint kis tudós lényeket kezdték látni. Olyan lényekként, akik a társas és fizikai környezetükról elméleteket bontakoztatnak ki, s ezeket az elméleteket próbálják aktív megfigyeléssel vagy

kisérletezéssel ellenórizni.

Gopnik és mások egyenesen arról beszélnek, hogy „bölcsek vannak a bölcsóben". 
amerikai feketék egyszerübben butábbak. Az 5. táblázat mutatja Jensen és ellenfeleinek érvelését. A korabeli vitáról lásd Pléh (2002) összefoglalóját.

5. táblázat. Az öröklött IQ-vita két tábora

\begin{tabular}{|l|l|l|}
\hline \multicolumn{1}{|c|}{ Jensen tézise } & \multicolumn{1}{c|}{ Következmények } & \multicolumn{1}{c|}{ Ellenfelek } \\
\hline $\begin{array}{l}\text { Az IQ a társadalmi } \\
\text { különbségek kulcsa }\end{array}$ & Egyféle kognitív képesség van & Sokféle kognitív eltérés van \\
\hline $\begin{array}{l}\text { Az IQ-különbségek } \\
\text { öröklöttek }\end{array}$ & $\begin{array}{l}\text { Az iskoláztatás sikerének } \\
\text { kulcsa, az IQ nem növelhető }\end{array}$ & $\begin{array}{l}\text { Az IQ-különbségek a korai } \\
\text { tapasztalás eredményei }\end{array}$ \\
\hline $\begin{array}{l}\text { A társadalmi különbségek } \\
\text { öröklöttek }\end{array}$ & $\begin{array}{l}\text { Az iskolai siker nem } \\
\text { társadalmi igazságtalanság }\end{array}$ & $\begin{array}{l}\text { Az IQ iskolai és társadalmi } \\
\text { kultusza igazságtalan }\end{array}$ \\
\hline
\end{tabular}

2019 táján már 5000 hivatkozás volt Jensen cikkére. A már sokszor emlegetett Stephen Jay Gould $A z$ elméricskélt ember címü könyve, amely önmagában 11000 hivatkozást hozott, áttekintette a szerinte, illetve valójában is téves intelligencia-tesztelés hagyományát, a hozzá kapcsolódó társadalmi diszkriminációs gyakorlatokat, és érzelmileg is hangsúlyosan fogalmazta meg radikális elutasító véleményét. „Egyszer élünk ebben a világban. Kevés nagyobb tragédia lehet kiterjedtebb, mint az életlehetőségek eltorlaszolása. Kevés igazságtalanság mélyebb, mint ha megtagadjuk a küzdelem, vagy akár a remény lehetőségét azzal, hogy egy kívülröl jövő korlátot, hamisan, mint belül lévő akadályt fogalmazunk meg." (Gould, 2000. 61-62.)

Az optimisták beavatkozásának alapja James Hunt (1906-1991) egy híres könyve volt az értelem és tapasztalás kapcsolatáról (Hunt, 1961). Hunt a modern kognitív pszichológiából kiindulva azt hirdette, hogy az intelligencia valójában egy igen korán kialakuló, az első 3 év során kibontakozó problémamegoldási képesség. Egy későbbi összefoglalójában azt hangsúlyozta, hogy az első 3 év nagyon fontos az érzelmi és értelmi fejlödésben. „Nagyon fontos a kezdeményezés kialakulásában, ami a tanult tehetetlenséggel áll szemben, a bizalom kialakulásában, abban, hogy képesek vagyunk segítséget várni a felnőttektől és másoktól, az együttérzés, a kíváncsiság és a tanulási szokások kialakulásában, melyek kulcsfontosságúak a további képességek kialakulásában.”

Jensen provokatív cikkének megjelenésével nagyjából egy időben Richard Herrnstein (1930-1994), a Harvard Egyetem pszichológusa egy fontos cikket, majd könyvet publikált a meritokrácia természetéről (Herrnstein, 1973). Jensennek abból a gondolatából indul ki, hogy Amerikában az öröklött intelligencia határozza meg a társadalmi sikert. A következő logikát fejti ki.

- A mentális képességek öröklöttek.

- A társadalmi sikerhez ezekre van szükség.

- A jövedelem és a tekintély a sikerektől függ.

- A társadalmi helyzet az emberek öröklött különbségein alapszik.

- A társadalmi különbségek növekszenek, mivel az IQ egyre inkább öröklötté válik.

- Mindezek megkérdőjelezik a modern társadalmi beavatkozási programokat.

Érdekes módon a későbbiekben, az 1980-as évektől, részben az eredeti, az 1970-es években lezajlott viták furcsa társadalmi következményeként, az amerikai egyetemeken és másutt is, a kompenzációs nevelési programok helyét a multikulturalizmus, a különbözö fekete és egyéb kisebbségi tanulmányi programok váltják fel. Alternatív kultúrák jelennek meg az egyetemeken, ahol a kérdés most már nem az, hogy vannak-e különbségek vagy nincsenek a társadalmi csoportok és etnikai csoportok között, hanem, hogy ezeket a különbségeket el kell fogadnunk az oktatásban. Ez azonban nem vezetett szükségszerüen 
a társadalmi egyenlőtlenségek csökkenéséhez, akár az iskolázásban, akár a munkaerőpiacon.

Mindez nagyon érdekes módszertani ízt kapott annak révén is, hogy sok öröklési érvelés Cyril Burt (1972) adataira támaszkodott. Burt, a híres brit intelligenciakutató adatairól azonban a halála után kiderült, hogy elnagyoltak, vagy egyenesen hamisítottak. Ugyanakkor az adatok érvényességével kapcsolatban volt egy nagyon fontos logikai érv. Az öröklött tulajdonságok létéből nem következik, hogy társadalmi csoportok között is ugyanaz lenne a helyzet. Ha végiggondoljuk, a testmagasság öröklött különbségeiböl nem következik az, hogy korai fehérjedús táplálkozással ne lehetne növelni a testmagasságot, mint arra számtalan példa utal. A lényeges az egész érvelésben az volt, hogy a csoportok közötti különbségek eredetére nem lehet következtetni az ikerkutatásokból. Herrnstein és Murray (1994) egy újabb könyvében lényegében ugyanezt a meritokratikus érvelést újította fel. Az amerikai társadalomban a javak egyenlőtlen elosztása lényegében az intelligencia öröklött eltéréseiből fakad. A progresszív és a konzervatív tábor a társadalomtudományban és a pszichológiában újra harcba került egymással. Van azonban a kérdésnek egy izgalmasabb mozzanata. Vajon a környezet fokozatos kulturális standardizációjával megjelenik-e a nagyobb esély az előrelépésre? Általában az derül ki, hogy magasabb kulturális szinten az intelligenciának nagyobb szerepe van. A hosszú, évtizedes beavatkozási kutatásokat értelmezve az egyik kiváló intelligenciakutató rámutat arra, hogy talán a motivációs mozzanatok fontosabbak. „A környezetgazdagító programok lehetnek fontosak, mivel egy részük hosszú távú pozitív hatást mutat az élet kimenetelére, s lehet, hogy a rövid távú IQ-növelések közvetítik ezt. Akkor vannak hosszú távú intelligencia-hatásai a programoknak, ha arra tanítják meg a gyerekeket, hogy a programon kívül hogyan küzdjenek meg azokkal a kognitív szempontból nagy kívánalmakat érvényesítő helyzetekkel, melyek a programban megvoltak, s, hogy ezek megmaradjanak." (Dickens és Flynn, 2001. 366.) Elötérbe kerülnek a motivációs tényezők. Bronfenbrenner és Ceci (1994) kapcsolták össze ezt a kérdést a fejlődési mechanizmusokkal. Bronfenbrenner, a szenior szerző, a Kennedy elnöksége alatt elindított előny-programok egyik gesztora volt. Évtizedek múlva arra a következtetésre jutott, hogy jó fejlődési helyzetben éppenséggel nagyobb lesz a genetika szerepe. „Amikor a proximális folyamatok gyengék, vagyis szegénység mellett, a hatékony pszichológiai múködés genetikailag megalapozott müködései kevéssé valósulnak meg. Amikor azonban a proximális folyamatok javulnak, vagyis jobb társadalmi helyzetben, nagyobb mértékben fognak megjelenni. A megvalósíthatatlan képességeket aktualizálhatják azok a társadalompolitikák és programok, amelyek a proximális folyamatoknak való kitettséget növelik a környezetben, mégpedig olyan környezetben, melyek ezeknek a hatékonyságát növelik." (Bronfenbrenner és Ceci, 1994. 569., 583.)

\section{Fejlődési zavarok és a moduláris fejlődés}

A generikus innátista táboron belül specifikus javaslatok merültek fel arra, hogy milyen módon kapcsolódhat össze a genetikai meghatározottság valamilyen fejlödési zavarral. Ez a pszicho-genetikus kutatási mód 3 fö módszert használ.

a) Ikerkutatások. Egypetéjü és kétpetéjü ikreket összehasonlítva természetesen közelebb kerülünk a genetika szerepéhez az egyéni eltérések keletkezésében.

b) Egyéni különbségek összekapcsolása a molekuláris genetikával. Ilyenkor vagy egy jelölt, kiválasztott gént tekintünk s vetjük össze változatait, például hiányát vagy megkettőződését a viselkedés változataival. Például a dopamin, egy energizáló idegrendszeri átvivő anyag kódolásáért felelős gén ún. hosszú alléljét vetjük össze a rámenős személyiségtípussal, s ennek pszichopatológiájával. A másik stratégiában 
teljes genomikus áttekintéssel, az egyedi DNS bázisokat érintő polimorfizmusokat próbáljuk összekapcsolni a pszichológiai különbségekkel. Ilyenkor a tüt keressük a szalmakazalban, s ritkán kapunk megbízható eredményeket, amit a genetikusok is tudnak. Valahol találnak egy különbséget mondjuk a szerelmi hódítás génjeiben, ami egy másik vizsgálatban nem fog megismétlődni.

c) Genetikai fejlődési zavarú csoportok vizsgálata. Itt a generikus nativista gondolatmenet összekapcsolódik a modularitással és a genetikával, s az egyéni különbségek kérdéskörével. A gondolatmenet lényege az, hogy ha találunk olyan csoportot, melynek tagjainál egy bizonyos genetikai rendellenesség egy fejlődési rendellenességgel kapcsolódik össze, akkor alátámasztjuk a moduláris meghatározottságot, ezzel azt, hogy egy mentális müködésért egy genetikailag meghatározott alrendszer a felelös. Ebben többnyire a Teubertől (1955) származó kettős disszociációs logikát használjuk. A kettős disszociáció lényege az, hogy az állatoknál a tapintási és látási diszkrimináció függetlenségét például akkor tudjuk kimutatni, ha találunk olyan állatot, vagy létre tudunk hozni olyan agysérült állatot, akinél csak az egyik teljesítmény romlik. Ennek az elvnek megfelelően újraértelmezték a hagyományos neuropszichológia számos gondolatmenetét, például a Broca- és a Wernicke-afázia különbségét. Központi szerepet játszott újabban a szociális megismerés ilyen típusú értelmezése is. Az autizmus úgy jelent meg, mint ahol viszonylag érintetlen kognitív fejlődés kapcsolódik össze kifejezetten a gondolatolvasás és a társas kogníció nehézségeivel (Baron-Cohen, 1995, Győri 2006).

Hasonló volt a nyelvfejlödési nehézségek értelmezése is. Eric Lenneberg (1974) vetette fel először az 1960-as években, hogy ha a nyelv az emberre specifikus genetikailag kódolt rendszer, akkor kell legyenek speciális nyelvi zavarok. Ez beilleszkedett Chomsky átfogó innátista érvmenetébe (Pléh, 2014b). Évtizedek múlva Mira Gopnik és Crago (1991) nevezetes cikke talált egy olyan családot, ahol a családtagok egy része, jellegzetes öröklésmenetet mutatva, nehezen tudott megbirkózni a nyelvtani morfológiával. Olyanokat mondtak, hogy „He go”, „They goes” stb. Ezt a zavart nevezték el specifikus nyelvi zavarnak (SLI), mely fokozatosan igen népszerü kutatási témává vált. Számos értelmezése lett. A legélesebb disszociációkat Pinker (2002) hangsúlyozta. Szerinte az SLI gyerekeknek kifejezetten a nyelvtannal vannak nehézségeik, míg a szókinccsel nincsenek. Szembeállították őket a Williams-szindrómás fejlődési zavart mutató gyerekekkel, akiknek viszont a nyelvtannal nem lennének problémáik, ellentétben a szókinccsel, amellyel igen. Ennek megfelelően a SLI gyerekeknek nincsenek különleges nehézségeik az angol nyelvben a rendhagyó múlt idővel, mint a „went”, „,came” stb. Ezeket mint elemeket tanulják meg. Az átlagos gyermekekhez képest ugyanakkor nehézségeik vannak a szabályos alakokkal, mint „,limbed”, „,walked”, mert ezeket is mint elemeket tanulják meg. Nagy vita kezdődött ezzel kapcsolatban. Sokan megkérdőjelezték a modellt. Lukács Ágnes magyar adatai szerint nincsen ilyen világos kettős disszociációs különbség (Pléh, Kas és Lukács, 2008). Kiderült az is, elsősorban Dorothy Bishop (2001) kutatásaiból, hogy a nyelvi zavart mutató gyerekeknek vannak nehézségeik a munkaemlékezetben, vagyis nem igaz, hogy mindenben jól müködnének. A munkaemlékezeti zavart mutató gyerekek inkább megfelelnek az alapvető SLI mintázatnak. A mikrogenetika is gondokat okozott. Lai és munkatársai (2001) a híres, Gopnik által leírt családban egy FOXP2 néven emlegetett gént találtak, amely óriási sajtóvisszhangot kapott, ugyanakkor kiderült, hogy ennek a génnek több változata van az állatvilágban, s valószínü, hogy eredetileg a finommozgásos ellenőrzésre vonatkozott (Venetianer, 2012). „Az, hogy a FOXP2 más állatoknál is jelen van, természetesen nem csökkenti relevanciáját a nyelvre vonatkozóan, hanem ismét arra utal, hogy az evolúció meglévő ösvényeit használja fel a rendszer. Lehet, hogy a nyelvben érintett genetikai utak más agyi rendszerekben 
is szerepet játszanak, de ez nem azt jelenti, hogy ugyanazokra a neurális rendszerekre támaszkodnak, mint a többi rendszer. Lehet például, hogy a nyelvtani hierarchiák leképezésének képességét ugyanolyan gének befolyásolják, mint amelyek hierarchikus tervezést más területeken, például a mozgásban is eredményeznek." (Marcus és Fischer, 2003. 261.) Vagyis egy kicsit csalódott a kutatás abban, hogy az SLI segítségével egyszerre tudjuk alátámasztani a modularitást és az innátizmust. Mára sokkal kevésbé vált ez specifikussá, sokkal inkább egy átfogó nyelvi zavar, ahogy Lukács Ágnes utal rá. A szigorú innátizmust egy lazább rendszer váltja fel. Ennek tágabb sugallatai is vannak. Nehéz lenne egy teljesen genetikailag megalapozott moduláris rendszert elképzelni sok száz modullal. Azt is tudjuk, hogy az embernél sajátos kulturális mechanizmusok vannak, melyek a viszonylag motiválatlan önkényes kulturális rendszerek hajlékony tanulását teszik lehetővé (Csibra és Gergely, 2009).

„A származás modifikációkkal modell, vagyis a darwinizmus genetikai értelmezése azt sugallja, hogy a különböző modulok közt kell legyenek megosztott tulajdonságok, de ha még modulok nem is lennének, akkor is lehetnek megosztott tulajdonságok a mögöttes neurális szerveződésben. Nincs független adatunk a két elmélet közötti választásra. Empirikus feladat igazolni bármely területen a modularitást." (Marcus, 2006. 462.)

\section{Irodalom}

Adjerid, I. \& Kelley, K. (2018). Big data in psychology: A framework for research advancement. American Psychologist, 73, 899-917. DOI: 10.1037/ amp0000190

Amundson, R. (2006). EvoDevo as Cognitive Psychology. Biological Theory, 1, 10-11. DOI: 10.1162/ biot.2006.1.1.10

Andler, D. (2016). La silhouette de l'humain. Paris: Gallimard.

Arbib, M. (2005). From monkey-like action recognition to human language: An evolutionary framework for neurolinguistics. Behavioral and Brain Sciences, 28(2), 105-124. DOI: 10.1017/s0140525x05000038

Bäckman, L. \& Holsten, von, C. (2002, szerk.). Psychology at the turn of the millennium. Vol. 1 and 2. Hove: Taylor and Francis. DOI: Vol. 1. 10.4324/ 9780203989418, Vol. 2. 10.4324/9780203989432

Barkow, J. H., Cosmides, L. \& Tooby, J. (1992, szerk.). The adapted mind. New York: Oxford University Press.

Baron-Cohen, S. (1995). Mindblindness: an essay on autism and theory of mind. Cambridge, Ma.: MIT Press. DOI: 10.7551/mitpress/4635.001.0001

Bartsch, K. \& Wellman, H.M. (1995). Children Talk About the Mind. New York: Oxford University Press.

Bishop, D. (2001). Genetic and environmental risks for specific language impairment in children. Philos. Transc. Royal Soc., B, 356, 369-380. DOI: 10.1098/ rstb. 2000.0770

Block, N. (1980, szerk.). Readings in the philosophy of psychology. Cambridge: Harvard University Press.
Bolhuis, J. J., Brown, G. R, Richardson, R. C. \& Laland, K. (2011). Darwin in Mind: New Opportunities for Evolutionary Psychology. PLoS Biology, 9(7), 1-8. DOI: 10.1371/journal.pbio.1001109

Boyd, R. \& Richerson, P. J. (1985). Culture and the Evolutionary Process. Chicago: University of Chicago Press.

Brady, W. J. \& mtsai (2017). Emotion shapes the diffusion of moralized content in social networks. Proceedings of the National Academy of Sciences, 114, 7313-7318. DOI: 10.1073/pnas.1618923114

Bródy Gábor (2010). Darwin és Napóleon. [Ismertetés Jerry Fodor \& Massimo Piattelli-Palmarini What Darwin Got Wrong c. könyvéröl.] Századvég, 56, (R) EVOLÚCIÓ, 121-130.

Bronfenbrenner, U. és Ceci, S. J. (1994). Nature-Nurture Reconceptualized in Developmental Perspective: A Bioecological Model. Psychological Review, 101, 568-586. DOI: 10.1037/0033-295x.101.4.568

Buller, D. J. (2005b). Evolutionary psychology: The emperor's new paradigm. Trends in Cognitive Sciences, 9(6), 277-283. DOI: 10.1016/j.tics.2005.04.003

Burt, C. (1972). The Inheritance of General Intelligence, American Psychologist, 27, 175-190. DOI: 10.1037/h0033789

Buss, D. M. (1984) Evolutionary biology and personality psychology Toward a conception of human nature and individual differences. American Psychologist, 39, 1135-1147. DOI: 10.1037//0003066x.39.10.1135 
Buss, D. M. (2001). Evolúciós pszichológia: Új paradigma a pszichológia tudománya számára. In Pléh Csaba, Csányi Vilmos \& Bereczkei Tamás (szerk.), Lélek és evolúció. Budapest: Osiris. 375-425.

Buss, D. (2002). Veszélyes szenvedély. Budapest: Vince. Campbell, D. (2001). Evolúciós ismeretelmélet. In Pléh Csaba, Csányi Vilmos \& Bereczkei Tamás (szerk.), Lélek és evolúció. Budapest: Osiris. 336-375.

Changeux, J. P. (2008). Az igazság és az ember. Budapest: Gondolat.

Changeux, J. P. (2012). Agyunk által világosan: A neuronális ember. Budapest: Typotex.

Changeux, J. P. \& Dehaene, S. (1989). Neuronal models of cognitive functions. Cognition, 33, 63-109. DOI: 10.1016/0010-0277(89)90006-1

Changeux, J.-P. \& Ricoeur, P. (2001). A természet és a szabályok. Budapest: Osiris.

Chomsky, N. (2018). Miféle teremtmények vagyunk? Budapest: Kossuth.

Churchland, Patricia (1986). Neurophilosophy. Cambridge, Mass.: MIT Press.

Churchland, P. M. (1995). The Engine of Reason, the Seat of the Soul. A Philosophical Journey into the Brain. Cambridge, Mass.: MIT Press.

Coates, J. (2015). A félszerzet órája. A kockázatvállalás biológiája a pénzpiacokon. Budapest: Typotex.

Cohen, J. (1994). The Earth is Round ( $\mathrm{p}<0.05$ ). American Psychologist, 49, 997-1003. DOI: 10.1037//0003-066x.49.12.997

Cole, M. (2005): Kulturális pszichológia. Egy letünt, majd újraéledö tudományág. Budapest: Gondolat.

Cosmides, L. \& Tooby, J. (2001) Evolúciós pszichológia: alapozó kurzus. In Pléh Csaba, Csányi Vilmos \& Bereczkei Tamás (szerk), Lélek és evolúció. Budapest: Osiris. 311-335.

Cowan, W. M., Harter, D. H. \& Kandel, E. R. (2000). The Emergence of Modern Neuroscience: Some Implications for Neurology and Psychiatry. Annual Review of Neuroscience, 23, 343-391. DOI: 10.1146/ annurev.neuro.23.1.343

Crozier, S., Sirigu, A., Lehéricy, S. \& mtsaik (1999). Distinct prefrontal activations in processing sequence at the sentence and script level: An FMRI study. Neuropsychologia, 37, 1469-1476. DOI: 10.1016/ s0028-3932(99)00054-8

Csibra, G. \& Gergely, G. (2009). Natural pedagogy. Trends in Cognitive Sciences, 13, 148-153. DOI: 10.1016/j.tics.2009.01.005

Damasio, A. (1996). Descartes tévedése. Budapest: Aduprint.

Dehaene, S. és Cohen, L. (2007). Cultural recycling of cortical maps. Neuron, 56, 384-398. DOI: 10.1016/j.neuron.2007.10.004
Dennett, D. C. (1978). Beliefs about Beliefs. Behavioral and Brain Sciences, 1, 568-570. DOI: 10.1017/ s0140525x00076664

Dennett, D. (1996). Micsoda elmék. Budapest: Kulturtrade.

Dennett, D. (1998): Az intencionalitás filozófája. Budapest: Osiris.

Dennett, D. (2010). Darwin veszélyes gondolata. 2. kiadás. Budapest: Typotex.

Dickens, W. T. \& Flynn, J. R. (2001). Heritability estimates versus large environmental effects: the IQ paradox resolved. Psychological Review, 108, 346-369. DOI: 10.1037//0033-295x.108.2.346

Donald, M. (2001). Az emberi gondolkodás eredete. Budapest: Osiris

Donald, M. (2018). The evolutionary origins of human cultural memory. In Wagoner, B. (szerk.), Handbook of culture and memory. Oxford: Oxford University Press. 19-40. DOI: 10.1093/oso/9780190230814.003.0002

Edelman, G. M. (1987). Neural Darwinism: The theory of neural group selection. New York: Basic Books.

Edelman, G. (1990). The remembered present: A biological theory of consciousness. New York: Basic Books.

Eysenck, H. (1997). Rebel with a cause. New Brunswick, NJ.: Transaction Publishers. DOI: 10.4324/ 9781315128108

Fiske, A. (1992). The four elementary types of sociality. Psychological Review, 69, 689-723. DOI: 10.1037//0033-295x.99.4.689

Fodor J. (1996a). Összefoglalás Az elme modularitásához. In Pléh (1996, szerk.), Kognitiv tudomány. Budapest: Osiris.

Fodor, J. (1996b). Fodor kalauza a mentális reprezentációhoz: Az intelligens nagynéni segédlete. In Pléh (1996, szerk.), Kognitiv tudomány. Budapest: Osiris.

Fodor, J. (1998). In critical condition: Polemical essays on cognitive science and the philosophy of mind. Cambridge: MIT Press.

Fodor, J. (2000). The mind doesn't work that way. Cambridge, MA: MIT Press. DOI: 10.7551/mitpress/4627.001.0001

Gergen, K. (1978). Experimentation in social psychology: A reappraisal. European Journal of Social Psychology, 8, 507-527. DOI: 10.1002/ejsp.2420080407

Gergely György \& Csibra Gergely (2007, szerk.). Ember és kultúra. A kulturális tudás eredete és átadásának mechanizmusai. Budapest: Akadémiai.

Gernsbacher, M. A. (1990): Language comprehension as structure building. Hillsdale, Erlbaum. DOI: 10.4324/9780203772157 
Goodale, M. A. és Milner, B. (1995). The visual brain in action. Oxford, Oxford University Press. DOI: 10.1093/acprof:oso/9780198524724.001.0001

Gopnik, M. \& Crago, M. B. (1991). Familial aggregation of a developmental language disorder. Cognition, 39, 1-50. DOI: 10.1016/0010-0277(91)90058-c

Gould, S. J. (1997). Darwinian Fundamentalism and Evolution: The Pleasures of Pluralism. New York Review of Books, June 12, 34-37.; June 26, 47-52.

Gould, S. L. (2000). Az elméricskélt ember. Budapest: Typotex.

Gould, S. J. \& Lewontin, R. C. (1979). The Sprandels of San Marco and the Panglossian paradigm: A critique of the adaptationist program. Proceedings of the Royal Society, B205, 581-598. DOI: 10.1098/ rspb.1979.0086

Gould, S. J. \& Vrba, E. S. (1982). Exaptation - a missing term in the science of form. Paleobiology, 8 , 4-15. DOI: $10.1017 / \mathrm{s} 0094837300004310$

Györi, M. (2006). Autism and cognitive architecture. Domain specificity and cognitive theorizing on autism. Budapest: Akadémiai.

Hebb, D. O. (1975): A pszichológia alapkérdései. Budapest: Gondolat.

Herrnstein, R. J. (1973). I.Q. in the Meritocracy. Boston: Little Brown.

Herrnstein, R. J. \& Murray, C. (1994). The Bell Curve. New York: Free Press.

Humphrey, N. K. (1976). The social function of intellect. In Bateson, P.P. G. \& Hinde, R. A. (szerk.), Growing points in ethology. Cambridge: Cambridge University Press. 303-317.

Hunt, J. M. (1961). Intelligence and experience. New York: Ronald Press.

Hunt, J. M. (1979). Psychological development: early experience. Annual Review of Psychology, 30, 103143. DOI : 10.1146/annurev.ps.30.020179.000535

Jacob, F. (1986). A lehetséges és a tényleges valóság. Budapest: Európa.

Jeannerod, M. \& Jacob, P. (2005). Visual cognition: a new look at the two-visual systems model. Neuropsychologia, 43, 301-312. DOI: 10.1016/j.neuropsychologia.2004.11.016

Jensen, A. R. (1969). How Much Can We Boost IQ and Scholastic Achievement? Harvard Educational Review, 39, 1-123. DOI: 10.17763/ haer.39.1.13u15956627424k7

Jerne, N. K. (1985). The generative grammar of the immune system. Science, 229, 1057-1059. DOI: 10.1126/science.4035345

Kahneman, D. (2013). Gyors és lassú gondolkodás. Budapest: HVG Könyvek.
Karmiloff-Smith, A. (1996): Túl a modularitáson: A kognitív tudomány fejlődéselméleti megközelítése. In Pléh Csaba (szerk.), Kognitiv tudomány. Budapest: Osiris.

Kéri, Sz. \& Gulyás, B. (2003). Four facets of a single brain: behaviour, cerebral blood flow/ metabolism, neuronal activity and neurotransmitter dynamics. Neuroreport, 14, 1097-1106. DOI: 10.1097/00001756-200306110-00001

Kosslyn, S. M. (1994). Image and Brain: The Resolution of the Imagery Debate. Cambridge, MA: MIT Press. DOI: $10.7551 /$ mitpress/3653.001.0001

Kovács, Á. M., Téglás, E. \& Endress, A. D. (2010). The social sense: susceptibility to others' beliefs in human infants and adults. Science, 330, 1830-1834. DOI: 10.1126/science.1190792

Kovács Ilona (2002). Funkcionális és fejlődésbeli disszociációk a látókéregben. In Vizi E. Szilveszter, Altrichter Ferenc, Nyíri Kristóf \& Pléh Csaba (szerk.), Agy és tudat. Budapest: BIP Kiadó. 221-230.

Lai, C. S. L., Fisher, S. E., Hurst, J. A., Vargha-Khadem, F. \& Monaco, A. P. (2001). A forkhead-domain gene is mutated in a severe speech and language disorder. Nature, 413, 519-523. DOI: 10.1038/35097076

Landau, B. \& Jackendoff, R. (2003). A „mi” és a „hol” a téri nyelvben és a téri megismerésben. In Lukács Ágnes, Király Ildikó, Racsmány Mihály \& Pléh Csaba (szerk.), A téri megismerés és a nyelv. Budapest: Gondolat. 69-125.

Latour, B. (1999). Sohasem voltunk modernek. Budapest: Osiris

Lenneberg, E. (1974). A nyelv biológiai szempontból. In: Pap Mária (szerk.): A nyelv keletkezése. Budapest: Kossuth. 111-128.

Leslie, A. (1987). Pretense and representation: The origins of the ,theory of mind”. Psychological Review, 94, 412-426. DOI: 10.1037//0033-295x.94.4.412

Lévi-Strauss, C. (1962). La pensée sauvage. Párizs: Plon.

Lurija, A. R. (1975). Válogatott tanulmányok. Budapest: Gondolat.

Levin, J. (2016). Functionalism. In Zalta, E. (szerk.), The Stanford Encyclopedia of Philosophy. Winter 2016 Edition. https://plato.stanford.edu/archives/ win2016/entries/functionalism

Marcus, G. F. (2006). Cognitive Architecture and Descent with Modification. Cognition 101, 443-465. DOI: 10.1016/j.cognition.2006.04.009

Marcus, G. F. (2008). Cludges. The haphasard construction of the human mind. Boston: Houghton Mifflin.

Marcus, G. F. \& Fisher, S. E. (2003). FOXP2 in focus: what can genes tell us about speech and language? Trends in Cognitive Sciences, 7, 257-262. DOI: 10.1016/s1364-6613(03)00104-9 
McDonald, S. (1998): Communication and language disturbances following traumatic brain injury. In Stemmer, B. \& Whittaker, H. A. (szerk.): Handbook of neurolinguistics. San Diego: Academic Press. 485-494. DOI: 10.1016/b978-012666055-5/50038-1

McKinnon, S. (2005). Neo-liberal genetics. The myths and moral tales of evolutionary psychology. Chicago, Ill.: Prickly Paradigm Press.

Meehl, P. (1967). Theory-testing in psychology and physics: A methodological paradox. Philosophy of Science, 34, 103-115. DOI: 10.1086/288135

Neuroskeptic (2012). The Nine Circles of Scientific Hell. Perspectives on Psychological Science, 7, 643-644. DOI: 10.1177/1745691612459519

Ogden, R. M. (1911). The unconscious bias of laboratories. Psychological Bulletin, 8. 330-331. DOI: $10.1037 / \mathrm{h} 0066327$

Open Science Cooperation (2015). Estimating the reproducibility of psychological science. Science, 349(6251). DOI: 10.1126/science.aac4716

Perner, J. (1991). Understanding the representational mind. Cambridge, Mass.: MIT Press.

Piatelli-Palmarini, M. (1996): Evolúció, szelekció és megismerés. In Pléh (1996, szerk.), Kognitív tudomány. Budapest: Osiris.

Pickering, M. J. \& Garrod, S. (2004). Toward a mechanistic psychology of dialogue. Behavioral and Brain Sciences, 27, 169-226. DOI: 10.1017/s0140525x 04000056

Pinker, S. (2002). Hogyan müködik az elme? Budapest: Osiris Kiadó.

Pinker, S. (2006). A nyelvi ösztön. 2. kiadás. Budapest: Typotex Kiadó.

Pinker, S. \& Ullman, M. T. (2002). The past and future of the past tense. Trends in Cognitive Sciences, 6, 456-463. DOI: 10.1016/s1364-6613(02)01990-3

Pléh Csaba (1996, szerk.). Kognitív tudomány. Budapest: Osiris.

Pléh Csaba (2002). Öröklés- és környezetelvű érvelés az 1970-es évek fordulóján. Magyar Pszichológiai Szemle, 57, 39-50. DOI: 10.1556/mpszle.57.2002.1.3

Pléh Csaba (2014a). A tér és a nyelv világa. Budapest: MTA

Pléh Csaba (2014b). Az innátizmus színeváltozásai - a filozófiától a genetikáig. Általános Nyelvészeti Tanulmányok XXVI. 193-220.

Pléh Csaba, Csányi Vilmos \& Bereczkei Tamás (2001, szerk.). Lélek és evolúció. Budapest: Osiris.

Pléh, Cs. \& Boross, O. (2015). Darwinism as a decryption key for the human mind. In Scott, R. \& Kosslyn, S. (szerk.). Emerging Trends in the Social and Behavioral Sciences: An Interdisciplinary, Searchable, and Linkable Resource. Wiley Online Library. DOI: 10.1002/9781118900772.etrds0070
Pléh, Cs., Csibra, G. \& Richerson, P. (szerk., 2014). Naturalistic approaches to culture. Budapest: Akadémiai.

Pléh Csaba, Kovács Gyula \& Gulyás Balázs (2006, szerk.). Kognitív idegtudomány. Budapest: Osiris.

Pléh Csaba, Kas Bence \& Lukács Ágnes (2008). A nyelvi fejlődés zavarai In: Kállai János, Bende István, Karádi Kázmér \& Racsmány Mihály (szerk.), Bevezetés a neuropszichológiába. Budapest: Medicina, 287-337.

Popper, K. (2009). Test és elme. Az interakció védelmében. Budapest: Typotex.

Popper, K. R. \& Eccles, J. C. (1977). The self and its brain. Berlin: Springer. DOI: 10.1007/978-3-64261891-8

Posner, M. I. (1976). Chronometric explorations of mind. Oxford: Oxford University Press.

Posner, M. I. \& Raichle, M. E (1994). Images of Mind. San Francisco: Scientific American Books.

Premack, D. \& Woodruff, G. (1978). Does the chimpanzee have a theory of mind? Behav. Brain Sceinces, 4, 515-526. DOI: 10.1017/s0140525x00076512

Robert, J. S. (2008). Taking old ideas seriously: Evolution, development, and human behavior. New Ideas in Psychology, 26, 387-404. DOI: 10.1016/j. newideapsych.2007.07.014

Rosenthal, R. (1966). Experimenter effects in behavioral research. New York: Appleton-Century-Crofts.

Ryle, G. (1999). A szellem fogalma. Budapest: Osiris. Spelke, E. \& Kinzler, K. D. (2007). Core knowledge. Developmental Science, 10, 89-96. DOI: 10.1111/j.14677687.2007.00569.x

Sperber, D. (2001). A kultúra magyarázata. Naturalista megközelítés. Budapest: Osiris.

Sperry, R. (1980). Mind-brain interaction: Mentalism, yes; dualism, no. Neuroscience, 5, 195-206. DOI: 10.1016/0306-4522(80)90098-6

Sperry, R. (1995). The future of psychology. American Psychologist, 50, 505-506. DOI: 10.1037/0003066x.50.7.505

Teuber, H. L. (1955). Physiological psychology. Annual Review of Psychology, 6, 267-96. DOI: 10.1146/annurev.ps.06.020155.001411

Tomasello, M. (2002). Gondolkodás és kultúra. Budapest: Osiris.

Tomasello, M. (2010). Az együttmüködés eredete. Budapest: Gondolat.

Tomasello, M. (2019). Becoming Human. A Theory of Ontogeny. Cambridge, MA: Harvard University Press. DOI: 10.4159/9780674988651 
Tooby, J. \& Cosmides, L. (1990). On the universality of human nature and the uniqueness of the individual: The role of genetics and adaptation. Journal of Personality, 58, 17-68. DOI: 10.1111/j.1467-6494.1990. tb00907. $x$

Ullman M. T. (2001). A neurocognitive perspective on language: The declarative/procedural model. Nature Reviews Neuroscience, 2, 717-726. DOI: $10.1038 / 35094573$

Ullman M. T. (2004).Contributions of memory circuits to language: the declarative/procedural model. Cognition, 92, 231-270. DOI: 10.1016/j.cognition.2003.10.008
Ungerleider, L. G. \& Mishkin, M. (1982). Two cortical visual systems. In Ingle, D. J., Goodale, M. A. \& Mansfield, R. J. W., Analysis of visual behavior. Cambridge, MA: MIT Press. 549-586.

Uttal, W. R. (2001). The new phrenology: the limits of localizing cognitive processes in the brain. Cambridge, MA: MIT Press.

Venetianer, P. (2011). Létezik-e a tagolt emberi beszéd képességéért felelős gén? Magyar Tudomány, 171, 907-912.

Yarbus, A. L. (1967). Eye movements and vision. New York: Plenum Press. 